\section{UDC 536.24}

V. I. Havrysh ${ }^{1}$, Dr. Sc. (Tech.), Assoc. Prof., orcid.org/0000-0003-3092-2279,

L. I. Kolyasa ${ }^{1}$, Cand. Sc. (Phys.-Math.), orcid.org/0000-0002-9690-8042,

O. M. Ukhanska ${ }^{1}$, Cand. Sc. (Phys.-Math.), Assoc. Prof., orcid.org/0000-0003-4408-5491,

V. B. Loik ${ }^{2}$, Cand. Sc. (Tech.),

orcid.org/0000-0002-3772-1640
DOI: $10.29202 /$ nvngu/2019-1/5

1 - Lviv Polytechnic National University, Lviv, Ukraine, email: kolyasa.lubov@gmail.com

2 - Lviv State University of Life Safety, Lviv, Ukraine

\title{
DETERMINATION OF TEMPERATURE FIELD IN THERMALLY SENSITIVE LAYERED MEDIUM WITH INCLUSIONS
}

Purpose. Determination of the field of temperature which is caused by the presents of the heat flow thermally sensitive (thermo-physical parameters which depend on temperature) layered medium which contains through foreign inclusions.

Methodology. It is based on the use of generalized functions; this enables us to express the coefficient of heat conductivity for such a structure as something integral, provided the heat contact between conjugated surfaces of the layers and the inclusion is ideal. In this case, the boundary value problem is reduced to solving a single equation of heat conduction with discontinuous coefficients under the given boundary conditions at the boundary surfaces of the medium.

Findings. The heat flux is concentrated at one of the boundary surfaces of the medium, the other boundary surface is thermally insulated. There exists ideal heat contact at the surfaces of the conjugated layers. To determine temperature regimes in such a medium, a nonlinear equation of heat conduction with nonlinear boundary conditions is used. In order to solve the nonlinear boundary value problem of heat conduction, we introduce a linearizing function which enables us to obtain a partially linearized differential equation and linear boundary conditions to determine this function. After the piecewise-linear approximation of temperature with respect to spatial coordinates is carried out, a linear differential equation with discontinuous coefficients in the linearizing function is obtained. An analytical-numerical solution of the obtained linear boundary value problem is found with the use of Fourier integral transformation which determines the linearizing function and enables us to obtain calculation formulae for calculating temperature. For a two-layer medium with an inclusion, temperature distribution for a linear temperature dependence of the coefficient of heat conductivity of the material is found, and a comparative numerical analysis of the distribution of temperature is made with corresponding distribution for constant coefficients of heat conductivity of the materials of the layers (materials of the layers are Y12 and 08 steels). Calculation formulae for determining the distribution of temperature in a two-layer medium with a through inclusion are obtained in the work. Numerical calculations of the distribution in a layer and in a two-layer medium for constant and for linearly variable with respect to temperature coefficient of heat conductivity of materials of the layers are performed.

Originality. There has been carried out a partial linearization of nonlinear boundary value problem; due to this, we have obtained formulae for determination of the distribution of temperature in a thermo-sensitive piece-wise homogeneous medium.

Practical value. The practical value consists in the increase in accuracy calculation of temperature fields and in effectiveness of methods for investigation of thermo-sensitive piece-wise homogeneous media. The precision is achieved at the expanse of taking into account the piecewise homogeneous structure of the medium and that of the dependence of the coefficient of heat conductivity of the materials of the medium on temperature (nonlinear model).

Keywords: heat conduction, isotropic, temperature field, inclusion foreign, thermally sensitive layered medium, heat flux, heat contact

Introduction. Analysis of the recent research and publications. Construction of the mathematical models which describe heat processes mountain ranges, mine cavities, in building and operations of mining enterprises, and others, is an urgent problem. The processes of heat transfer in layered mountain ranges are described by two- and three-dimensional stationary equations of heat conduction with taking into account the nonlinear effects in the bulk of the Earth, these equations are also used as approximated mathematical model of systems which contain shaft mounting con-

(C) Havrysh V. I., Kolyasa L. I., Ukhanska O. M., Loik V. B., 2019 crete casing, lintels, and other articles of mining enterprises.

It is considered that the average temperature of the Earth's crust is equal to $15^{\circ} \mathrm{C}$. Surface temperature variations can penetrate inside the earth, but to a limited depth. Daily variations vanish at a depth of $1-2 \mathrm{~m}$, and annual (seasonal) variations at a depth of $10-40 \mathrm{~m}$ (with the exception of regions of eternal frost). The depth at which seasonal variations of temperature vanish is called the neutral level. Experimental investigations indicate that below the neutral level the temperature field of the Earth's crust practically does not vary with time, but just increase with the increase in the depth, this confirms the 
presence of heat flow from the center of the Earth to its surface. The Earth's crust consists of different kinds of layers, in particular, one of them can be a rock-bed. The geothermal (natural rock bed) temperature at a certain depth is determined according to the following relationship

$$
\left(t_{r b}=t_{0}+G_{t} y\right)
$$

where $t_{0}$ is the average temperature of the neutral layer (in the territory of Ukraine $t_{0} \approx 289 \mathrm{~K}$ ); $y$ is depth which is measured from the neutral level to the place of the rock-bed location; $G_{t}=\frac{d t}{d y}$ is the geothermal gradient. In practical investigations, for Ukraine the value of the geometric gradient is chosen to be equal to $2.7 \cdot 10^{-2} \mathrm{~K} / \mathrm{m}$. But numerous measurements indicate that its values change at the depths where oil or gas beds are located, which causes the change in the temperature of the bed; and this, in its turn, causes the change in viscosity of fluids, of capillary forces, of rheological properties of fluids, of interphase exchange, and others. Therefore, in order to increase the current debits and in order to increase the oil extraction (especially from beds of oil of high viscosity) the temperature is to be increased by means of heat generation or by means of injection of hot heat agents. In order to determine the power of heat source, it is necessary to know the distribution of the temperature $t$ with respect to the depth $y$, this enable us to obtain the value of the geothermic gradient $G_{t}$ for different values of the depth $y$ within a bed.

In the monograph [1], mathematical models of heat and mass transfer in mountain ranges and cavities have been considered and analyzed as well as the main principles of creation of theoretical geothermal physics. Non-unidimensional models of mine thermos-physics and methods for solving boundary-value problems of heat transfer in mountain ranges are presented in the paper [2]. Analytical method for investigation of heatexchange processes under the condition of resourcesaving technologies, under accumulation and withdrawal in boneless rocks are considered in [3].

In the paper [4], the external asymptotic expansion of the solution of the non-stationary problem of heat conduction for layered anisotropic nonhomogeneous plates at face surfaces of which second kind boundary conditions are set has been carried out. The obtained 2D equations with the help of which we solve the problem have been analyzed. Asymptotic properties of the solutions of the problem have been investigated. The evaluation of accuracy with which the temperature in a plate beyond the boundary layer is considered as piece-wise linearly or piece-wise quadratically distributed with respect to the thickness of the layer structure has been obtained. Physical substantiation of some peculiarities of asymptotic expansion of temperature has been presented.

By means of finite differences method, using the procedure of quasi-linearization, the solution of the non-linear boundary value problem [5] of heat conduction has been obtained. The process of heat transfer has been investigated in a layered plate whose components were of different transparency being connected by a thin intermediate layer under conditions of heat irradiation from the side of partially transparent layer. Having introduced an effective coefficient of reflection at the surface of the contact, we have found approximated equalities for determination of the field of radiation in the main and, partially, in the transparent layers.

It was as early as in [6] that some investigation on temperature fields for thermosensitive elements of structure which are of piece-wise homogeneous structure.

Article [7] solved a non-stationary problem on thermal conductivity and thermoelasticity for functionalgradient thick-wall spheres. Thermal-physical and thermoelastic parameters of materials, except for Poisson's coefficient, are arbitrary functions of the radial coordinate.

Axisymmetric stationary problem on thermal conductivity and thermoelasticity of the hollow functionally gradient areas relative to the heat source was considered. The solutions are obtained as functions from spatial coordinates for temperature, the displacement component vector and stress tensor by using boundary conditions for radial and angular coordinates [8].

In paper [9], a thermoelasticity solution for steady state response of thick cylinders which are subjected to pressure and external heat flux in inner surface is presented.

A model of the process of non-linear heat conduction, the technique of linearization of the boundary value problem, and the relationships for calculation of the temperature field in a layered thermo-sensitive medium containing through inclusion and heated by a heat flow concentrated at one of its surfaces are presented below.

Mathematical model of the problem. Consider an isotropic infinite layered thermo-sensitive plate whose thickness is $2 \sigma$. The plate consists of $n$ heterogeneous layers of different widths and of different coefficients of heat conductivity and it is referred to a Cartesian system of coordinates $(x, y, z)$ the origin of which is located at one of the boundary surfaces (Fig. 1). The face $|z|=\delta$ is thermo-isolated. There is a foreign through inclusion in the plate. At the boundary surface $K_{0}=\{(x, 0, z):|x|<\infty$, $|z| \leq d\}$ in the domain $\Omega_{0}=\{(x, 0, z):|x| \leq h,|z| \leq d\}$ there is a concentrated heat flow whose surface density is $q_{0}=$ const. At the surfaces of the layers $K_{j}=\{(x, y, z)$ : $|x|<\infty,|z| \leq \delta\}(j=\overline{1, n-1})$ and at those of the inclusion $K_{ \pm}=\left\{( \pm h, y, z): 0 \leq y \leq y_{n}\right\},|z| \leq \delta$ there is an ideal heat contact $t_{j}=t_{j+1}, \lambda_{j}(t) \frac{\partial t_{j}}{\partial y}=\lambda_{j+1}(t) \frac{\partial t_{j+1}}{\partial y}$ for $y=y_{j}$ $(j=\overline{1, n-1}) ; \quad t_{0}=t_{j}, \lambda_{0}(t) \frac{\partial t_{0}}{\partial x}=\lambda_{j}(t) \frac{\partial t_{j}}{\partial x} \quad(j=\overline{1, n})$ for $|x|=h$ ( 0 for the inclusion, $j$ for the $j^{\text {th }}$ layer of the plate). The boundary surface $K_{n}=\left\{\left(x, y_{n}, z\right): K_{n}=|x|<\infty\right.$, $|z| \leq \delta\}$ of the plate is heat-insulated. The distribution of temperature $t(x, y)$ with respect to space coordinates is determined by means of solving the non-linear equation of heat conduction 


$$
\frac{\partial}{\partial x}\left[\lambda(x, y, t) \frac{\partial t}{\partial x}\right]+\frac{\partial}{\partial y}\left[\lambda(x, y, t) \frac{\partial t}{\partial y}\right]=0
$$

with boundary conditions

$$
\begin{gathered}
\left.t\right|_{|x| \rightarrow \infty}=0,\left.\quad \frac{\partial t}{\partial x}\right|_{|x| \rightarrow \infty}=\left.\frac{\partial t}{\partial y}\right|_{y=y_{n}}=0 \\
\left.\lambda_{0}(t) \frac{\partial t}{\partial y}\right|_{y=0}=-q_{0} S_{-}(h-|x|),
\end{gathered}
$$

where

$$
\lambda(x, y, t)=\sum_{j=1}^{n}\left\{\lambda_{j}(t)+\left[\lambda_{0}(t)-\lambda_{j}(t)\right] S_{-}(h-|x|)\right\} N\left(y, y_{j-1}\right)
$$

is the coefficient of heat conductivity of the non-homogeneous plate; $\lambda_{j}(t), \lambda_{0}(t)$ are the coefficients of heat conductivity of the materials of the $j^{\text {th }}$ layer of the plate and that of the foreign inclusion, respectively; $y_{0}=0$; $N\left(y, y_{j-1}\right)=S_{+}\left(y-y_{j-1}\right)-S_{+}\left(y-y_{j}\right) ; S_{ \pm}(\zeta)=$

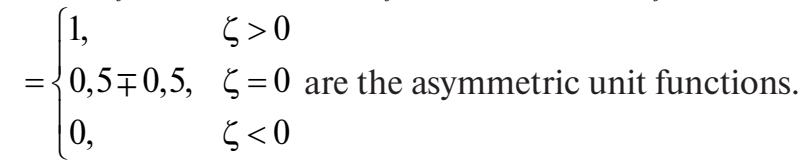
Let us introduce linearizing functions

$$
\begin{gathered}
\vartheta=\sum_{j=1}^{n}\left\{N\left(y, y_{j-1}\right) \int_{0}^{t(x, y)} \lambda_{j}(\zeta) d \zeta+\right. \\
+S_{-}(x+h)\left[N\left(y, y_{j-1}\right) \int_{t(-h, y)}^{t(x, y)}\left(\lambda_{0}(\zeta)-\lambda_{j}(\zeta)\right) d \zeta-\right. \\
-S_{+}\left(y-y_{j-1}\right) \int_{t\left(-h, y_{j-1}\right)}^{t\left(x, y_{j-1}\right)}\left(\lambda_{0}(\zeta)-\lambda_{j}(\zeta)\right) d \zeta S_{+}\left(y-y_{j-1}\right)+ \\
\left.+S_{+}\left(y-y_{j}\right) \int_{t\left(-h, y_{j}\right)}^{t}\left(\lambda_{0}(\zeta)-\lambda_{j}(\zeta)\right) d \zeta\right]- \\
-S_{+}(x-h)\left[N\left(y, y_{j-1}\right) \int_{t(h, y)}^{t(x, y)}\left(\lambda_{0}(\zeta)-\lambda_{j}(\zeta)\right) d \zeta-\right. \\
-S_{+}\left(y-y_{j-1}\right) \int_{t\left(h, y_{j-1}\right)}^{t\left(x, y_{j-1}\right)}\left(\lambda_{0}(\zeta)-\lambda_{j}(\zeta)\right) d \zeta+ \\
\left.+S_{+}\left(y-y_{j}\right) \int_{t\left(h, y_{j}\right)}^{\left.t x, y_{j}\right)}\left(\lambda_{0}(\zeta)-\lambda_{j}(\zeta)\right) d \zeta\right]- \\
-S_{+}\left(y-y_{j-1}\right) \int_{t\left(x, y_{j-1}\right)}^{\left.\lambda_{j}(\zeta) d \zeta+S_{+}\left(y-y_{j}\right) \int_{0}^{t\left(x, y_{i}\right)} \lambda_{j}(\zeta) d \zeta\right\} .}
\end{gathered}
$$

Having differentiated it with respect to the variables $x$ and $y$, we obtain

$$
\begin{aligned}
& \lambda(x, y, t) \frac{\partial t}{\partial x}=\frac{\partial \vartheta}{\partial x}-F_{1}(x, y) ; \\
& \lambda(x, y, t) \frac{\partial t}{\partial y}=\frac{\partial \vartheta}{\partial y}+F_{2}(x, y),
\end{aligned}
$$

where

$$
\begin{gathered}
F_{1}(x, y)=S_{+}(|x|-h) \sum_{j=1}^{n}\left\{\left.\left[\left(\lambda_{0}(t)-\lambda_{j}(t)\right) \frac{\partial t}{\partial x}\right]\right|_{y=y_{j-1}} \times\right. \\
\left.\times S_{+}\left(y-y_{j-1}\right)-\left.\left[\left(\lambda_{0}(t)-\lambda_{j}(t)\right) \frac{\partial t}{\partial x}\right]\right|_{y=y_{j}} S_{+}\left(y-y_{j}\right)\right\} ; \\
\times\left.\sum_{j=1}^{n}\left[\left(\lambda_{0}(t)-\lambda_{j}(t)\right) \frac{\partial t}{\partial y}\right]\right|_{|x|=h} N\left(y, y_{j-1}\right) .
\end{gathered}
$$

Taking into account the relations $(4,3)$ the initial problem (1-2) takes the following form

$$
\frac{\partial^{2} \vartheta}{\partial y^{2}}-\frac{\partial}{\partial x}\left[F_{1}(x, y)\right]+\frac{\partial}{\partial y}\left[F_{2}(x, y)\right]=0 .
$$

The boundary conditions with the use of the relation (3) are written the following way

$$
\begin{gathered}
\left.\vartheta\right|_{|x| \rightarrow \infty}=0,\left.\quad \frac{\partial \vartheta}{\partial x}\right|_{|x| \rightarrow \infty}=\left.\frac{\partial \vartheta}{\partial y}\right|_{y=y_{n}}=0 ; \\
\left.\frac{\partial \vartheta}{\partial y}\right|_{y=0}=-q_{0} S_{-}(h-|x|) .
\end{gathered}
$$

Thus, the non-linear equation of heat conduction (1) has been reduced to the partially linearized equation (5) for the linearizing function (3) with discontinuous coefficients, and the non-linear boundary conditions (2) to the completely linearized boundary conditions (6).

Analytical-numerical solution. Let us approximate the function $\mathrm{t}( \pm h, y), t\left(x, y_{j}\right)$ in terms of expression

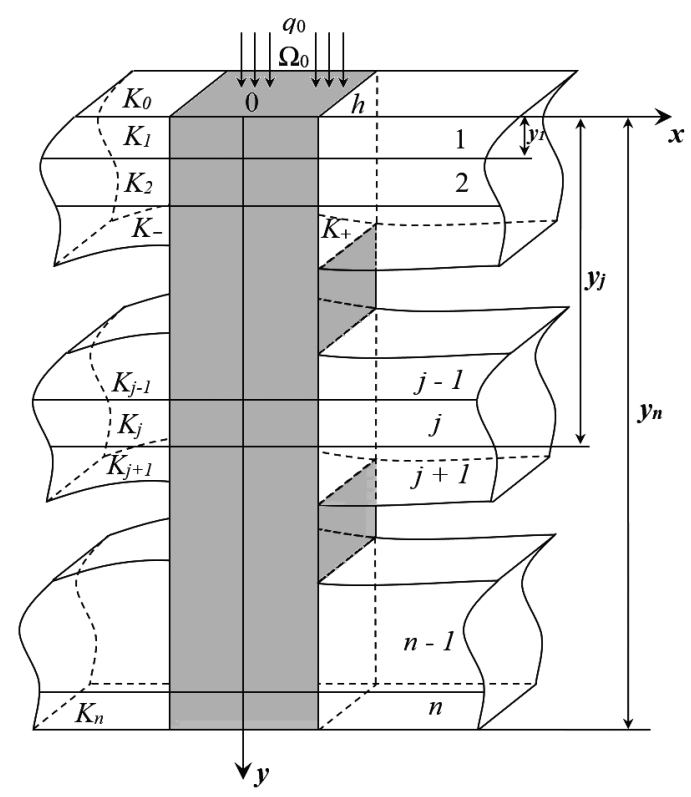

Fig. 1. Isotropic multilayered thermo-sensitive plate with through foreign inclusion by the plane $z=0$ 


$$
\begin{gathered}
t( \pm h, y)=t_{1}^{(j h)}+\sum_{k=1}^{m-1}\left(t_{k+1}^{(j h)}-t_{k}^{(j h)}\right) S_{-}\left(y-y_{k}^{(j)^{*}}\right) \\
t\left(x, y_{j}\right)=t_{1}^{(j)}+\sum_{l=1}^{p-1}\left(t_{l+1}^{(j)}-t_{l}^{(j)}\right) S_{-}\left(x-x_{l}\right)
\end{gathered}
$$

where

$$
\begin{gathered}
\left.y_{k}^{(j)^{*}} \in\right] y_{j-1} ; y_{j}\left[; y_{1}^{(j)^{*}} \leq y_{2}^{(j)^{*}} \leq \ldots \leq y_{m-1}^{(j)^{*}}\right. \\
\left.x_{l} \in\right] h ; x_{*}\left[; x_{1} \leq x_{2} \leq \ldots x_{p-1}\right.
\end{gathered}
$$

$m, p$ are the number of subintervals of the intervals $] y_{j-1} ; y_{j}[$ and $] h ; x_{*}\left[\right.$ respectively; $t_{k}^{(j h)}(k=\overline{1, m}), t_{l}^{(j)}(l=\overline{1, p})$ are unknown approximately values of temperature; $x_{*}$ is the value of the coordinate the temperature in which is practically equal to zero (determined from the equal corresponding linear boundary condition).

Let us substitute the relations (7) into (5) and obtain the partial linear differential equation for determination of the linearizing function $\vartheta$

$$
\Delta \vartheta=\sum_{j=1}^{n}\left[\sum_{l=1}^{p-1} F_{j}^{(l)}(y) \delta_{-}^{\prime}\left(x-x_{l}\right)-S_{-}(h-|x|) \sum_{k=1}^{m-1} F_{j}^{(k)}(y)\right],
$$

where

$$
\begin{gathered}
F_{j}^{(k)}(y)=\left(t_{k+1}^{(j h)}-t_{k}^{(j h)}\right)\left[\lambda_{0}\left(t_{k+1}^{(j h)}\right)-\lambda_{j}\left(t_{k+1}^{(j h)}\right)\right] \delta_{-}^{\prime}\left(y-y_{k}^{(j)^{*}}\right) \\
F_{j}^{(l)}(y)=\left(t_{l+1}^{(j-1)}-t_{l}^{(j-1)}\right)\left[\lambda_{0}\left(t_{l+1}^{(j-1)}\right)-\right. \\
\left.-\lambda_{j}\left(t_{l+1}^{(j-1)}\right)\right] S_{+}\left(y-y_{j-1}\right)- \\
-\left(t_{l+1}^{(j)}-t_{l}^{(j)}\right)\left[\lambda_{0}\left(t_{l+1}^{(j)}\right)-\lambda_{j}\left(t_{l+1}^{(j)}\right)\right] S_{+}\left(y-y_{j}\right)
\end{gathered}
$$

$\Delta=\frac{\partial^{2}}{\partial x^{2}}+\frac{\partial^{2}}{\partial y^{2}}$ is the Laplacian operator in Cartesian

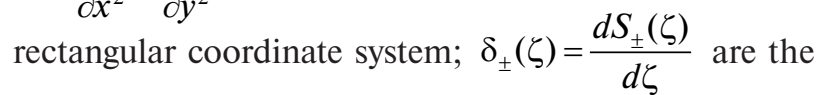
asymmetric Dirack delta functions [10].

Having applied Fourier integral transformation with respect to the spatial coordinate $x$ for the boundary value problem $(8,6)$, we obtain the ordinary second order differential equation with constant coefficients

$$
\begin{aligned}
\frac{d^{2} \bar{\vartheta}}{d y^{2}}-\xi^{2} \bar{\vartheta} & =-\frac{1}{\sqrt{2 \pi}} \sum_{j=1}^{n}\left[\frac{2 \sin \xi h}{\xi} \sum_{k=1}^{m-1} F_{j}^{(k)}(y)+\right. \\
& \left.+i \xi \sum_{l=1}^{p-1} e^{-i \xi x_{l}} F_{j}^{(l)}(y)\right],
\end{aligned}
$$

the boundary conditions for which are of the form

$$
\left.\frac{d \bar{\vartheta}}{d y}\right|_{y=y_{n}}=0 ;\left.\quad \frac{d \bar{\vartheta}}{d y}\right|_{y=0}=-\sqrt{\frac{2}{\pi}} \frac{q_{0}}{\xi} \sin \xi h,
$$

where $\bar{\vartheta}=\frac{1}{\sqrt{2 \pi}} \int_{-\infty}^{\infty} e^{i \xi x} \vartheta d x$ is Fourier image-function $\vartheta(x, y)$; $\xi$ is the parameter of Fourier transformation; $i^{2}=-1$.

Having solved the boundary value problem $(9,10)$ and having applied the inverse Fourier integral transformation to the obtained solution, we obtain

$$
\begin{gathered}
\vartheta=\frac{1}{\pi} \int_{0}^{\infty} \frac{1}{\xi}\left\{\sum _ { j = 1 } ^ { n } \left[\sum _ { l = 1 } ^ { p - 1 } \operatorname { s i n } \xi ( x - x _ { l } ) \left(\left(\left(1-\operatorname{ch} \xi\left(y-y_{j-1}\right)\right) \times\right.\right.\right.\right. \\
\left.\times S_{+}\left(y-y_{j-1}\right)+\frac{\operatorname{ch} \xi y}{\operatorname{sh} \xi y_{n}} \operatorname{sh}\left(y_{n}-y_{j-1}\right)\right)\left(t_{l+1}^{(j-1)}-t_{l}^{(j-1)}\right) \times \\
\times\left(\lambda_{0}\left(t_{l+1}^{(j-1)}\right)-\lambda_{j}\left(t_{l+1}^{(j-1)}\right)\right)-\left(1-\operatorname{ch} \xi\left(y-y_{j}\right)\right) S_{+}\left(y-y_{j}\right)+ \\
\left.\left.+\frac{\operatorname{ch} \xi y}{\operatorname{sh} \xi y_{n}} \operatorname{sh} \xi\left(y_{n}-y_{j}\right)\right)\left(t_{l+1}^{(j)}-t_{l}^{(j)}\right)\left(\lambda_{0}\left(t_{k+1}^{(j h)}\right)-\lambda_{j}\left(t_{k+1}^{(j h)}\right)\right)\right)- \\
-2 \sin \xi h \cos \xi x \sum_{k=1}^{m-1}\left(t_{k+1}^{(j h)}-t_{k}^{(j h)}\right)\left(\lambda_{0}\left(t_{k+1}^{(j h)}\right)-\lambda_{j}\left(t_{k+1}^{(j h)}\right)\right) \times \\
\left.\times\left(\operatorname{ch} \xi\left(y-y_{k}^{(j)^{*}}\right) S_{-}\left(y-y_{k}^{(j)^{*}}\right)-\frac{\operatorname{ch} \xi y}{\operatorname{sh} \xi y_{n}} \operatorname{sh} \xi\left(y_{n}-y_{k}^{(j)^{*}}\right)\right)\right]+ \\
\left.+\frac{2 q_{0}}{\xi} \sin \xi \cos \xi x \frac{\operatorname{ch} \xi\left(y-y_{n}\right)}{\operatorname{sh} \xi y_{n}}\right\} d \xi .
\end{gathered}
$$

The unknown approximation values $t_{k}^{(j h)}(k=\overline{1, m})$ and $t_{l}^{(j)} \quad(l=\overline{1, p})$ of the temperature field of the medium are determined from the system of linear equations which is obtained by means of substitution of the specific expressions of the coefficients of heat conductivity of materials of the layers of the plate and those the inclusion, which are dependent on temperature, into (3, 11).

Results of numerical calculations. As is indicated by investigations in many practical problems, the coefficients of heat conductivity are linearly dependent on temperature

$$
\lambda_{s}=\lambda_{s}^{0}\left(1-k_{s} t\right),
$$

where $\lambda_{s}^{0}, k_{s}$ are the reference and the temperature coefficients of heat conductivity of the materials of the inclusion $(s=0)$ and of the $j^{\text {th }}$ layers of the plate $(s=j)$, $j=\overline{1, n}$. From the expressions $(3,11)$ we obtain the formulae for determination of the temperature $t$ for the double-layer plate $(n=2)$ in the domains

$$
\begin{gathered}
\Omega_{1}=\left\{(x, y):|x|>h, 0 \leq y<y_{1}\right\}-t=\frac{\left.1-\sqrt{1-2 \frac{k_{1}}{\lambda_{1}^{0}}\left(\vartheta+\vartheta_{1}\right.}\right)}{k_{1}} \\
\Omega_{2}=\left\{(x, y):|x|>h, y_{1} \leq y \leq y_{2}\right\}-t= \\
=\frac{1-\sqrt{1-2 \frac{k_{2}}{\lambda_{2}^{0}}\left(\vartheta+\vartheta_{2}\right)}}{k_{2}} ; \\
\Omega_{3}=\left\{(x, y):|x| \leq h, 0 \leq y<y_{1}\right\}- \\
-t=\frac{1-\sqrt{1-2 \frac{k_{0}}{\lambda_{0}^{0}}\left(\vartheta+\vartheta_{3}\right)}}{k_{0}} \\
\Omega_{4}=\left\{(x, y):|x| \leq h, y_{1} \leq y \leq y_{2}\right\}- \\
-t=\frac{1-\sqrt{1-2 \frac{k_{0}}{\lambda_{0}^{0}}\left(\vartheta+\vartheta_{4}\right)}}{k_{0}} .
\end{gathered}
$$




$$
\begin{array}{r}
\text { Here } \vartheta_{1}=\left.\lambda_{1}^{0}\left[\left(1-\frac{k_{1}}{2} t\right) t\right]\right|_{y=0} ; \vartheta_{2}=\vartheta_{m}+\vartheta_{1} ; \vartheta_{m}= \\
=\left.\left[\left(\lambda_{2}^{0}-\lambda_{1}^{0}+\frac{\lambda_{1}^{0} k_{1}-\lambda_{2}^{0} k_{2}}{2} t\right) t\right]\right|_{y=y_{1}} ; \vartheta_{3}=\vartheta_{v}^{(1)}-\left.\vartheta_{v}^{(1)}\right|_{y=0}+\vartheta_{0} ; \\
\vartheta_{0}=\left.\lambda_{0}^{0}\left[\left(1-\frac{k_{0}}{2} t\right) t\right]\right|_{y=0} ; \vartheta_{v}^{(i)}=\left.\left[\left(\lambda_{0}^{0}-\lambda_{i}^{0}+\frac{\lambda_{i}^{0} k_{i}-\lambda_{0}^{0} k_{0}}{2} t\right) t\right]\right|_{|x|=h}, \\
i=1,2 ; \vartheta_{4}=\vartheta_{v}^{(2)}-\left.\vartheta_{v}^{(1)}\right|_{y=0}+\left.\vartheta_{m}\right|_{|x|=h}+\vartheta_{0}, \text { the value of }
\end{array}
$$

temperature $t(x, 0)$ is such which is equal to the ambient temperature; $t( \pm h, y), t\left(x, y_{1}\right)$ we calculate according to the formula (13) .

The relations $(13-16)$ completely describe the distribution of temperature in an infinite double-layer thermo-sensitive plate which contains a through foreign inclusion (Fig. 1).

For a monolayer plate of $2 l$ width which contains a through inclusion, there has been carried out numerical analysis of the dimensionless temperature $t^{*}=\lambda_{0} t /\left(q_{0} h\right)$ for the following initial data: the material of the plate was BK94-I ceramics, that of the inclusion was silver; the number of subintervals of the interval $]-l, l[$ was $n=10 ; l / h=1$. The aforesaid materials in the temperature interval $\left[20{ }^{\circ} \mathrm{C} ; 1230{ }^{\circ} \mathrm{C}\right]$ are described by the following dependencies of the coefficient of heat conductivity on temperature

$$
\begin{aligned}
& \lambda_{1}(t)=13.67 \frac{W}{K m}\left(1-0.00064 \frac{1}{K} t\right) ; \\
& \lambda_{0}(t)=422.54 \frac{W}{K m}\left(1-0.00031 \frac{1}{K} t\right),
\end{aligned}
$$

which is a particular case of the relationship (12).

The number of subintervals of the interval $]-l, l[$ is $n=10$ for aforesaid thermo-physical (reference and temperature coefficients of heat conductivity) and geometrical (length of inclusion and width of plate) parameters of the structure enable us to carry out calculation with an accuracy within $\varepsilon=10^{-6}$.

Let us consider a double-layer plate with uniformly distributed sources of heat at the surfaces of conjugated layers (Fig. 2). Let us assume that at the boundary surfaces $y=-y_{1}, y=y_{2}$ of the plate the values of temperature are $t_{1}=0{ }^{\circ} \mathrm{C}, t_{2}=700{ }^{\circ} \mathrm{C}$, respectively. The materials of the layers of the plate are $\mathrm{Y} 12$ steel and 08 steel.

In the temperature interval $\left[0{ }^{\circ} \mathrm{C} ; 700^{\circ} \mathrm{C}\right]$, the aforesaid materials are described by the following dependences of coefficient of heat conductivity on temperature

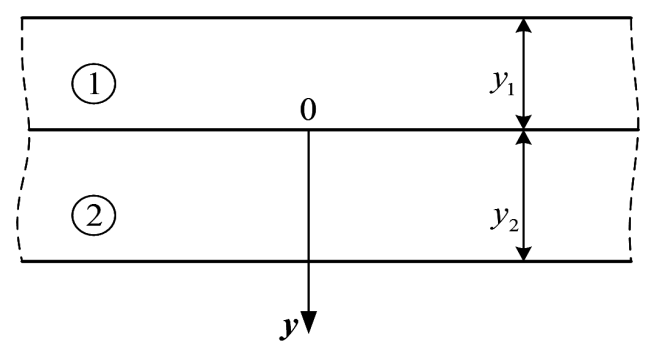

Fig. 2. Double layer plate

$$
\begin{aligned}
& \lambda_{1}(t)=47.5 \frac{W}{K m}\left(1-0.00037 \frac{1}{K} t\right) ; \\
& \lambda_{2}(t)=64.5 \frac{W}{K m}\left(1-0.00049 \frac{1}{K} t\right) .
\end{aligned}
$$

Numerical calculations of temperature field for a linear model (constant coefficient of heat conductivity of materials of layers of the plate; $\lambda_{1}=38.7 \mathrm{~W} /(\mathrm{Km}), \lambda_{2}=$ $=48.7 \mathrm{~W} /(\mathrm{Km}))($ Fig. 3, curve 1) have been carried out. The distribution of temperature for the nonlinear model (linearly variable coefficient of heat conductivity of materials of layers of the plate is expressed by the relation (18)) is depicted in Fig. 3 (curve 2); $y_{1}=y_{2}=1 \mathrm{~m}$.

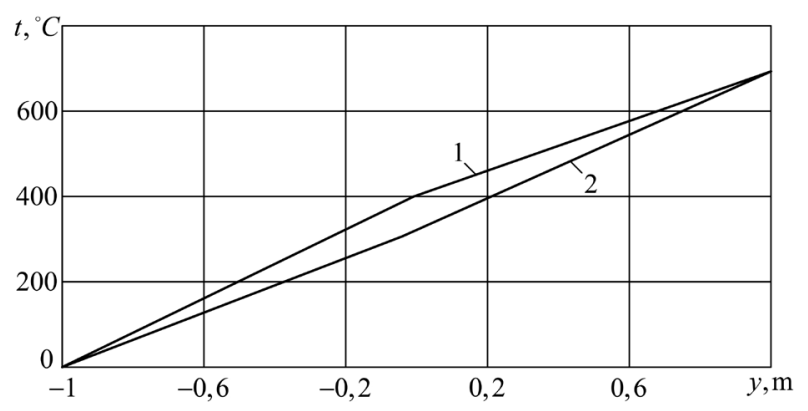

Fig. 3. Dependence of temperature $t$ on coordinate $y$ for constant (curve 1) and for linearly variables (curve 2) of coefficient of heat conductivity of materials of layers of the plate

The behavior of the curves indicates the correspondence between the mathematical model and the real physical process since at the surfaces $(x=0)$ of conjugated layers the satisfaction of conditions of ideal heat contact (no jump in temperature) is observed. The obtained results for the chosen materials under linear dependence of their coefficient of heat conductivity on temperature differ from the results which were obtained for constant coefficient of heat conductivity by $15 \%$.

Conclusion. The introduced linearizing function has enabled us to partially linearize the initial nonlinear equation of heat conduction and to completely linearize the boundary conditions; and the suggested piece-wise linear approximation of temperature at boundary surfaces of the inclusion and of foreign layers has enabled us to completely linearize the differential equation. This allowed us to apply Fourier integral transformation to the obtained linear problem with respect to the linearizing function and to construct its analytical numerical solution. Linear temperature dependence of the coefficient of heat conductivity for materials of inclusion and of the double layer plate was considered. On the basis of this, calculational formulae for calculation of temperature values in the considered structure have been derived. The results obtained for the chosen materials under linear dependence of coefficient of heat conductivity on temperature differ from the results which were obtained for constant coefficient of heat conductivity [10], by $7 \%$. Their inconsiderable divergence is accounted for by the fact that the real values of the temperature coef- 
ficient of heat conductivity for the considered materials are small.

The results obtained in the work can be used for further modeling of temperature states in non-uniform rocks with the aim to prognosticate operational and designing peculiarities of the operations of structures of mining.

\section{References.}

1. Vengerov, I.R., 2008. Thermophysics of shafts and mines. Mathematical models. Vol.1. Paradigm analysis. Donetsk: Nord-Press, 288 s. [pdf]. Available at: <https://www.e-reading.club/bookreader.php/137405/ Vengerov_-_Teplofizika_shaht_i_rudnikov._Matematicheskie_modeli.pdf> [Accessed 11 December 2017].

2. Vengerov, I. R., 2007. Non-one-dimensional models of miming thermophysics. Fiziko-tekhnicheskiye problemy gornogo proizvodstva. Sb. nauchn. tr., 10, pp. 60-80. Available at: <http://www.ifgpdnr.ru/main/doc/\%D0 $\% \mathrm{~A} 1 \% \mathrm{D} 0 \% \mathrm{~B} 1 \% \mathrm{D} 0 \% \mathrm{BE} \% \mathrm{D} 1 \% 80 \% \mathrm{D} 0 \% \mathrm{BD} \% \mathrm{D} 0 \% \mathrm{~B}$ $8 \%$ D0\%BA $20 \%$ D0\%A4\%D0\%A2\%D0\%9F\%D0\% 93\%D0\%9F\%202007.pdf > [Accessed 07 January 2018). 3. Smirnova, N. N., Nikolayeva, N. V., Brichkin, V. N. and Kuskov, V. B., 2014. Analytical solutions to certain problems of heat exchange in the processes of mining. Fiziko-tekhnicheskiye problemy razrabotki poleznykh iskopayemykh / Gornaya teplofizika, 1, pp. 80-86.

4. Nemyrovskyi, Yu. V., 2007. Asymptotic analysis of problems of transient heat conduction of embedded aeolotropic nonhomogeneous plates under boundary conditions of the first and third types on the face surface. Mathematical methods and physicomechanical fields [online], 50(2), pp. 160-175. Available at: <http://journals. iapmm.lviv.ua/ojs/index.php/MMPMF/article/ view/2184/2398> [Accessed 25 December 2017].

5. Turii, O., 2008. Nonlinear contact boundary problem of thermomechanics for the irradiated two-layer plate connected by an intermediate layer. Physico-mathematical modellingand informational technologies, 8, pp. 118-132. Available at: < http://dspace.nbuv.gov.ua/handle/123456789/22091> [Accessed 04 November 2017].

6. Havrysh, V. I., 2016. Research on temperature fields in a thermosensitive layer with a through inclusion. Physicochemical Mechanics of materials, 52(4), pp. 63-68.

7. Bayat, A., Moosavi, H. and Bayat, Y., 2015. Thermomechanical analysis of functionally graded thick spheres with linearly time-dependent temperature. Scientia Iranica, 22(5), pp. 1801-1812.

8. Mohazzab, A.H. and Jabbari, M., 2011. Two-Dimensional Stresses in a Hollow FG Sphere with Heat Source. Advanced Materials Research, 264-265, pp. 700-705. DOI: 10.4028/www.scientific.net/amr.264-265.700.

9. Ghannad, M. and Yaghoobi, M. P., 2015. A thermoelasticity solution for thick cylinders subjected to thermo-mechanical loads under various boundary conditions. International Journal of Advanced Design \& Manufacturing Technology, 8(4), pp. 1-12.

10. Havrysh, V. Y., 2015. Modeling of temperature conditions in non-homogeneous elements of electronic devices with through foreign inclusions. Electronic modeling, 37(4), pp. 109-118.

\section{Визначення температурного поля в термочутливому шаруватому середовищі із включенням}

\author{
В. І. Гавриш ${ }^{1}$, Л. І. Коляса ${ }^{1}$, О. М. Уханська ${ }^{1}$, \\ В. Б. Лоїк ${ }^{2}$
}

1 - Національний університет „Львівська політехніка“, м. Львів, Україна, е-mail: kolyasa.lubov@gmail.com 2 - Львівський державний університет безпеки життєдіяльності, м. Львів, Україна

Мета. Визначення температурного поля, зумовленого тепловим потоком, у термочутливому (теплофізичні параметри залежать від температури) шаруватому середовищі з наскрізним чужорідним включенням.

Методика. Базується на використанні узагальнених функцій, що дає можливість коефіцієнт теплопровідності для такої структури виразити як єдине ціле за умови ідеального теплового контакту між поверхнями спряження шарів і включення. У цьому випадку крайова задача зводиться до розв'язування одного рівняння теплопровідності 3 розривними коефіцієнтами за заданих крайових умов на межових поверхнях середовища.

Результати. Тепловий потік зосереджено на нижній межовій поверхні цього середовища, інша межова поверхня є теплоізольованою. На поверхнях спряження шарів існує ідеальний тепловий контакт. Температурні режими в такому середовищі описуються нелінійним рівнянням теплопровідності за нелінійних крайових умов. Для розв'язання нелінійної крайової задачі теплопровідності введено лінеаризуючу функцію, що дала змогу отримати частково лінеаризоване диференціальне рівняння та лінійні крайові умови для визначення цієї функції. За допомогою кусково-лінійної апроксимації функції температури за просторовими координатами отримане лінійне диференціальне рівняння відносно лінеаризованої функції, коефіцієнти якого є розривними. 3 використанням інтегрального перетворення Фур'є знайдено аналітично-числовий розв'язок лінеаризованої крайової задачі - лінеаризована функція, що дозволило отримати співвідношення для визначення температурного поля в середовищі. Для двошарового середовища, що містить включення, знайдено розподіл температури для випадку лінійної температурної залежності коефіцієнта теплопровідності матеріалів і проведено порівняльний числовий аналіз отриманого розподілу температури з відповідним розподілом для сталих коефіцієнтів теплопровідності матеріалів шарів (матеріали шарів - сталь У12 і 08). Визначено та проаналізовано розподіл температури для шару, виготовленого з кераміки ВK94-I, та наскрізного включення, виготовленого зі срібла. У роботі отримані співвідношення для визначення розподілу температури у двошаровому середовищі, що містить наскрізне включення. Проведені чисельні розрахунки цього розподілу у шарі та двошаровому середовищі при сталому й лінійно змінному від- 
носно температури коефіцієнті теплопровідності матеріалів шарів.

Наукова новизна. Полягає в тому, що введена лінеаризуюча функція, за допомогою якої проведено часткову лінеаризацію нелінійної крайової задачі теплопровідності, дала змогу отримати співвідношення для визначення розподілу температури в термочутливому кусково-однорідному середовищі.

Практична значимість. Полягає в підвищенні точності розрахунку температурних полів і ефективності методів дослідження термочутливих кусково-однорідних середовищ. Точність досягається за рахунок урахування кусково-однорідної структури середовища й залежності від температури коефіцієнтів теплопровідності матеріалів середовища (нелінійна модель).

Ключові слова: теплопровідність, ізотропність, температурне поле, тепловий потік, включення чужорідне, термочутливе шарувате середовище, теплоізольовані лицеві поверхні, тепловий контакт

\section{Определение температурного поля в термочувствительной слоистой среде с включением}

\author{
В. И. Гаврыш ${ }^{1}$, Л. И. Коляса ${ }^{1}$, О. М. Уханская ${ }^{1}$, \\ В. Б. Лоик ${ }^{2}$
}

1 - Национальный университет „Львовская политехника“", г. Львов, Украина, e-mail: kolyasa.lubov@gmail.com

2 - Львовский государственный университет безопасности жизнедеятельности, г. Львов, Украина

Цель. Определение температурного поля, обусловленного тепловым потоком, в термочувствительной (теплофизические параметры зависят от температуры) слоистой среде со сквозным инородным включением.

Методика. Базируется на использовании обобщенных функций, дает возможность коэффициент теплопроводности для такой структуры выразить как единое целое при условии идеального теплового контакта между поверхностями сопряжения слоев и включения. В этом случае краевая задача сводится к решению одного уравнения теплопроводности с разрывными коэффициентами при заданных краевых условиях на граничных поверхностях среды.

Результаты. Тепловой поток сосредоточен на нижней граничной поверхности этой среды, другая граничная поверхность является теплоизолированной. На поверхностях сопряжения слоев существует идеальный тепловой контакт. Температурные режимы в такой среде описываются нелинейным уравнением теплопроводности с нелинейными краевыми условиями. Для решения нелинейной краевой задачи теплопроводности введена линеаризующая функция, которая дала возможность получить частично линеаризованное дифференциальное уравнение и линейные краевые условия для определения этой функции. С помощью кусочнолинейной аппроксимации функции температуры по пространственным координатам получено линейное дифференциальное уравнение относительно линеаризующей функции, коэффициенты которого являются разрывными. С использованием интегрального преобразования Фурьє найдено аналитически-численное решение краевой задачи - линеаризующая функция, что позволило получить соотношения для определения температурного поля в среде. Для двухслойной среды с включением найдено распределение температуры для случая линейной температурной зависимости коэффициента теплопроводности материалов и проведен сравнительный численный анализ полученного распределения температуры с соответствующим распределением для постоянных коэффициентов теплопроводности материалов слоев (материалы слоев - сталь У12 и 08). Рассчитано и проанализировано распределение температуры для слоя, изготовленного из керамики ВК94-I, и сквозного включения, изготовленного из серебра. В работе получены соотношения для определения распределения температуры в двухслойной среде со сквозным включением. Приведены численные расчеты этого распределения в слое и в двухслойной среде для постоянного и линейно переменного относительно температуры коэффициента теплопроводности материалов слоев.

Научная новизна. Заключается в том, что проведена частичная линеаризация нелинейной краевой задачи теплопроводности, благодаря чему получены формулы для определения распределения температуры в термочувствительной кусочно-однородной среде.

Практическая значимость. Заключается в повышении точности расчета температурных полей и эффективности методов исследования термочувствительных кусочно-однородных сред. Точность достигается за счет учета кусочно-однородной структуры среды и зависимости от температуры коэффициента теплопроводности материалов среды (нелинейная модель).

Ключевые слова: теплопроводность, изотропность, температурное поле, тепловой поток, инородное включение, термочувствительная слоистая среда, теплоизолированные лицевые поверхности, тепловой контакт

Рекомендовано до публікації докт. фіз.-мат. наук Д. Б. Куриляком. Дата надходження рукопису 24.11.17. 